\title{
The U.S. electricity market twenty years after restructuring: A review experience in the state of Delaware
}

\author{
Wei-Ming Chen \\ Center for Applied Demography and Survey Research, University of Delaware, 288 Graham Hall, Newark, DE, 19716, USA
}

\section{A R T I C L E I N F O}

\section{Keywords:}

Electric market restructuring

Electricity rate

Customer choice

\begin{abstract}
A B S T R A C T
Electricity industry restructuring in the United States, which began in the 1990s, was aimed at enhancing market competitiveness and lead to efficient resource allocation and cost reduction. The state of Delaware was one of the earliest adopters of restructuring and has gained more than 20 years of experience. The retail customers in a restructured market had greater opportunities to choose between electricity generators. However, this research compares electricity prices and finds that restructured states have higher electricity rates than non-restructured states. A better understanding of the welfare and satisfaction of electricity customers in the context of restructuring is needed.
\end{abstract}

\section{Introduction}

Federal regulators in the United States started a wave of reform in monopolistic industries to advance market efficiency to the presumed benefit of consumers, beginning with railroads (1976) and following with airlines (1978) and public utilities (1978) (O'Connor, 2017). For the electricity industry in particular, the Public Utility Regulatory Policies Act (PURPA) of 1978 opened the generation sector by requiring electric utilities to purchase power from Independent Power Producers (IPPs). Regarding electric transmission, the Federal Energy Regulatory Commission (FERC) issued Order 888 in 1996, known as the "Open Access" order, which required the transmission-owning utilities to provide open, nondiscriminatory access at just and reasonable rates to all generators in the wholesale electricity market (Munson, 2005).

Along with the open access to the wholesale market governed by the FERC, a few state governments also started retail market reforms in the 1990s. Retail market restructuring started with California in 1996, and then spread to New Hampshire, New York, Pennsylvania, and Rhode Island. These states faced relatively high electricity costs (Joskow, 2000). The IPPs also exerted pressure on the state governments to increase their supply opportunities (Joskow, 2000). However, California experienced the Enron market-manipulation crisis during 2000-2001 and faced market failure (Cicchetti et al., 2004). Several states repealed or suspended their market restructuring process after California's experience $^{1}$ while other states continued. As of 2018, 13 states and the District of Columbia allowed retail markets (see Section 4) (Electric

\section{Choice, 2017).}

The goal of this research is to bridge the theoretical benefits with the empirical evidence of electricity market restructuring. This analysis applied both quantitative and qualitative methodologies. The electricity rates of restructured and non-restructured states are compared within the time period of 1990-2016. Restructuring in the state of Delaware is analyzed in detail in terms of the impact of restructuring on residential ratepayers. Delaware is considered one of the pioneering states of market restructuring. As a small state with one investor-owned distribution utility covering more than $60 \%$ of total retail sales, Delaware is a good case to study the benefits and challenges of a restructured electric market. This study provides detailed evidence of rate trends following market restructuring.

The next section reviews the structure of the electricity industry and summarizes previous studies on electricity market restructuring. Section 3 introduces the data and methodology. Section 4 compares electric rates between states with and without restructuring. Section 5 presents the restructuring history of the electric industry in Delaware and reviews the trends in retail rates and customer choice. Section 6 analyzes the rate cases proposed by the investor-owned distribution company in Delaware. Section 7 discusses the lessons from experiences of two decades of electricity restructuring in Delaware, draws conclusions, and provides policy implications.

\footnotetext{
E-mail address: katty@udel.edu.

${ }^{1}$ States that pulled back from deregulation post-Enron are Arizona, Arkansas, California, Montana, Nevada, New Mexico, Oklahoma, and West Virginia (Brockway, 2007).
} 


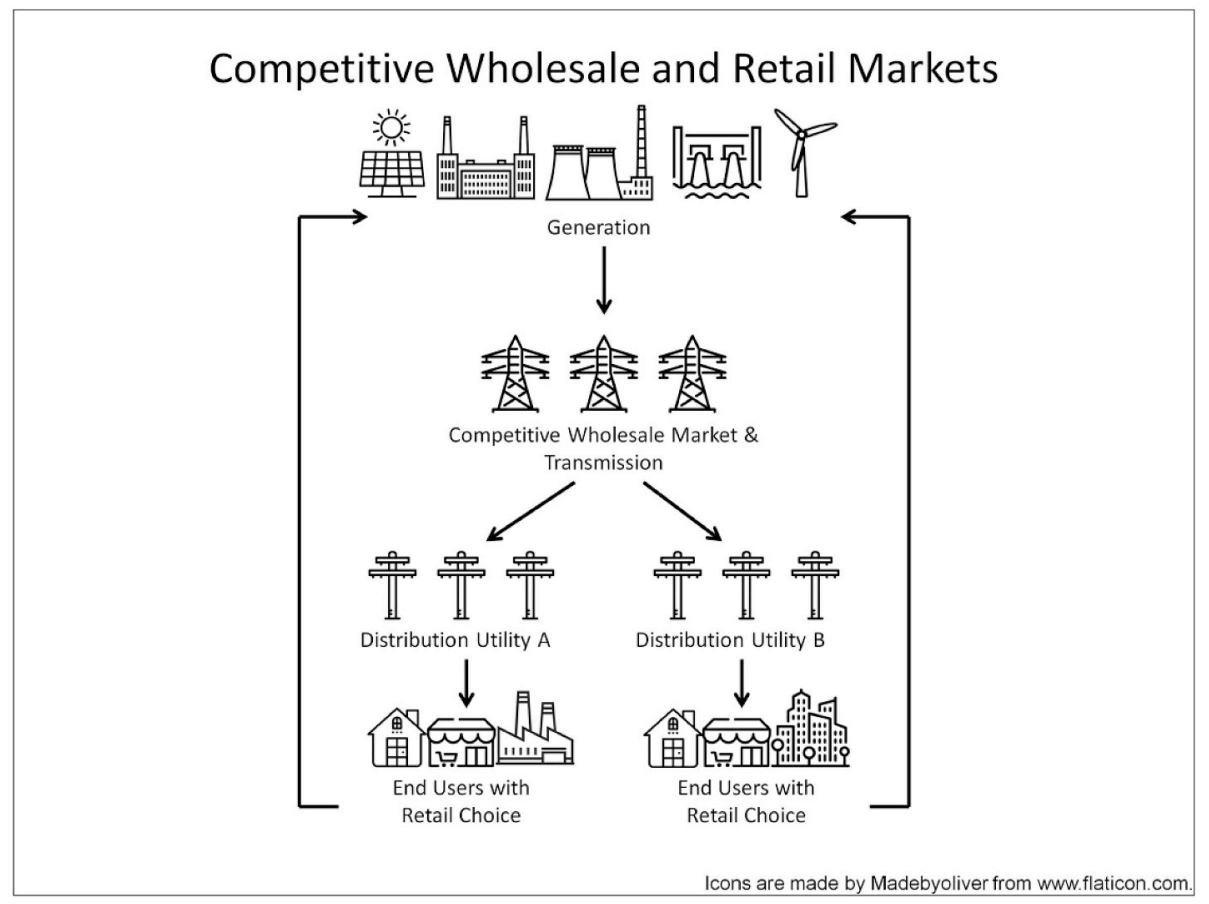

Fig. 1. The restructured electric supply system.

Source: Author created with icons made by Madebyoliver from www.flaticom.com.

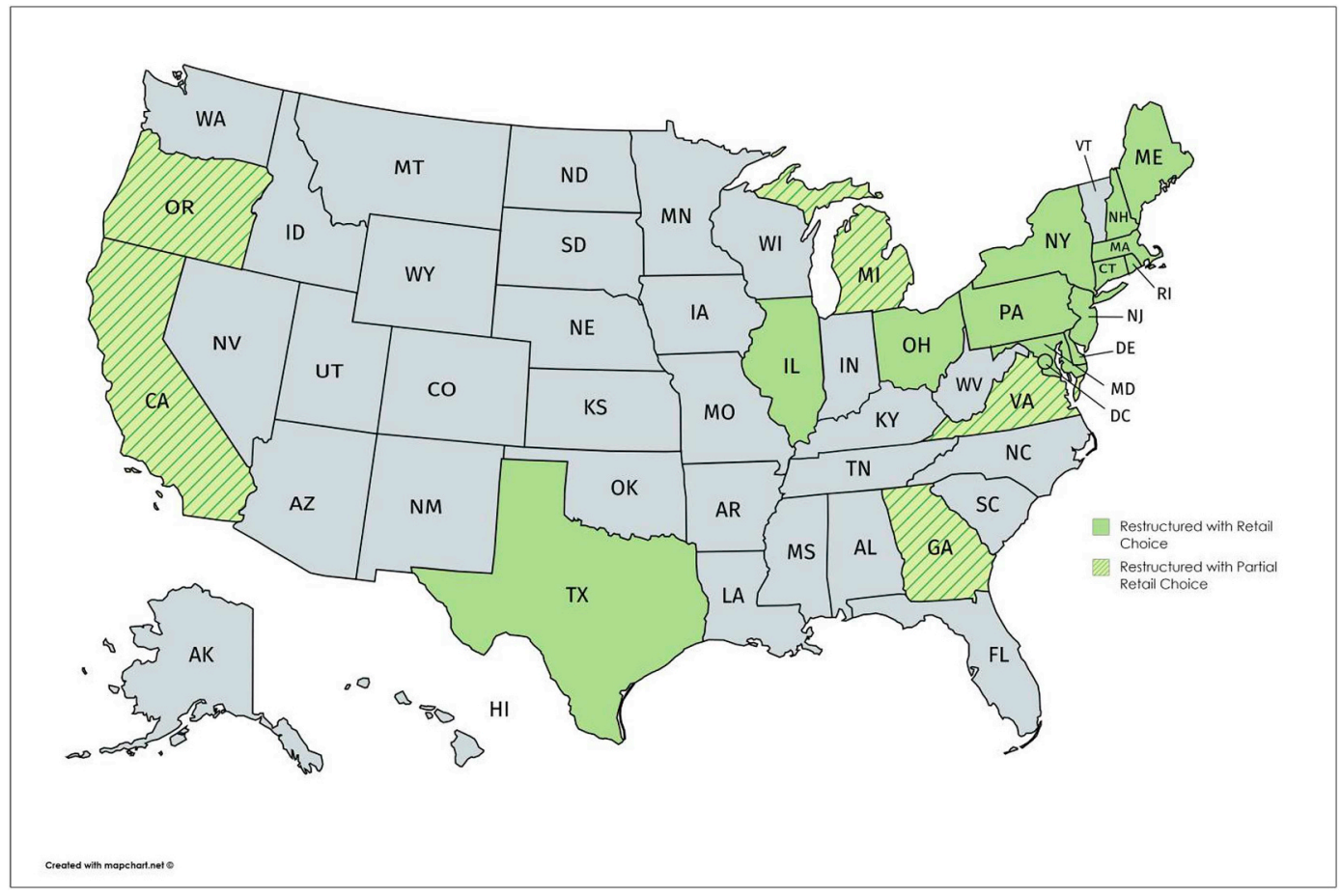

Fig. 2. Types of retail electricity markets.

Source: Data from the American Coalition of Competitive Energy Suppliers and Electric Choice (2017)

\section{Market structure and literature review}

\subsection{Electricity market structure in the United States}

The electricity industry is composed of three distinct sectors providing power generation, transmission, and distribution. Generators produce electricity from various primary energy sources (such as fossil fuels and renewable resources). High-voltage transmission grids and lower-voltage distribution networks deliver power to consumers (International Energy Agency, 2001; Purdue University Energy Center, n.d.). Under restructuring, the transmission grid was opened and generation competition was introduced. It is noteworthy that while restructuring, deregulation, and competitiveness are terms frequently interchanged in electricity market literature, these terms are not synonymous (Sioshansi, 2006, p. 69). Restructuring is the better term to describe the U.S. experience because deregulation and competition is 


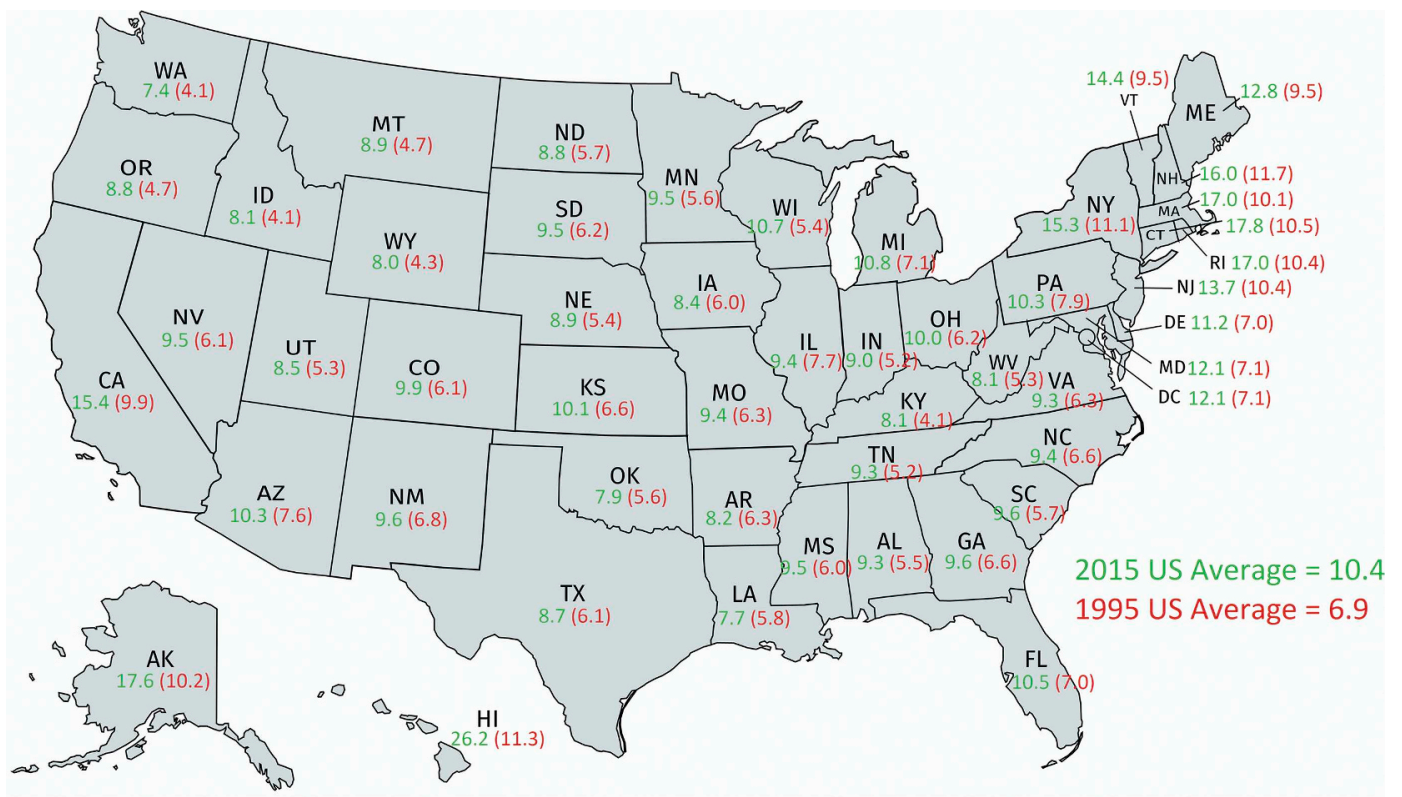

Fig. 3. Retail Electricity Rates in 1995 and 2015 (unit: cents/kWh).

Source: Data from the U.S. Energy Information Administration (2018).

Electricity Rates in 1995 and 2015

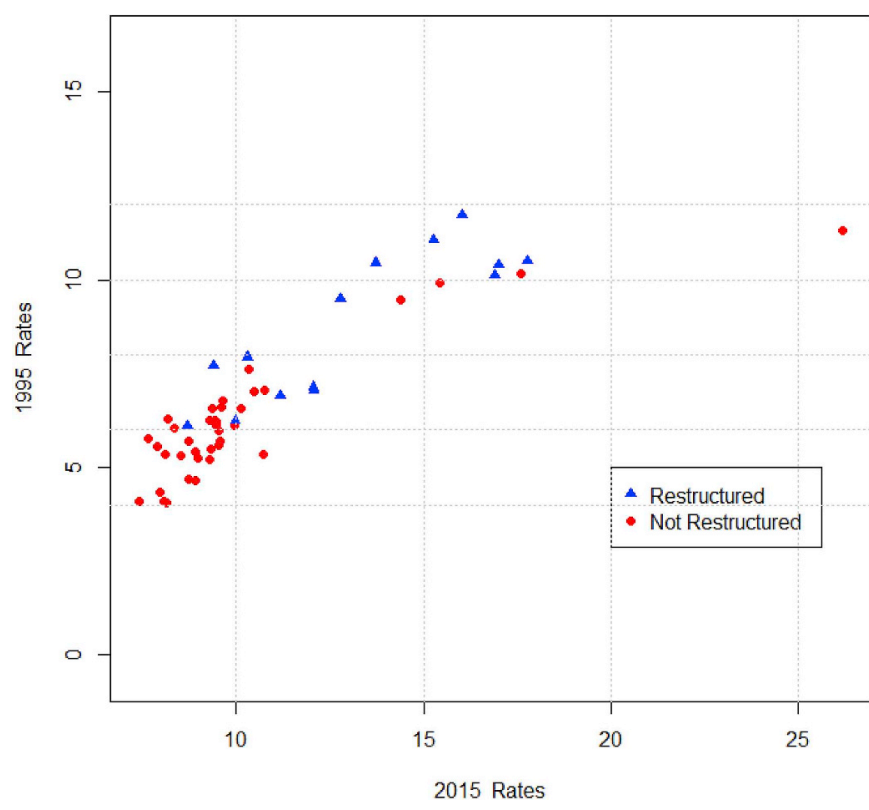

Fig. 4. Plots for electric rates for all states in 1995 and 2015.

Source: Data from the U.S. Energy Information Administration (2018). Note: The red dot outlier is Hawaii.

limited to the power generation sector (Hogan, 2002). In a restructured market with retail choice, customers can only choose the supplier, not the transmission or distribution provider.

In fact, restructuring occurred at two market levels: the wholesale market and the retail market (Fig. 1). A competitive wholesale market operates among generators serving utilities and large customers (Borenstein and Bushnell, 2000; Cicchetti et al., 2004). The Independent System Operators or Regional Transmission Organizations (ISOs/RTOs) were established in several U.S. regions to operate wholesale trade and electricity dispatch. Following restructuring, transmission grids remain federally regulated by FERC, and distribution grids remain state regulated.
A competitive retail market performs transactions between endusers and generators or possible intermediaries (including utilities and brokers) (International Energy Agency, 2001). End-use customers in a competitive retail market can choose electricity suppliers based on their preference (i.e., retail electricity choice) or remain with the standardized (default) option provided by the distribution utility. Alternative power suppliers offer different price models for the supply charge. The standardized price is determined by the wholesale market where the utilities purchase power. While customers are empowered to choose the electricity supplier in a competitive retail market, transmission and distribution services (poles, wire, and billing) remain with ISOs/RTOs and distribution utilities, respectively. Not every state with a competitive wholesale market embraces the competitive retail market and vice versa. Some states (such as Kansas, Oklahoma, and Minnesota) participate in restructured wholesale markets but have not adopted retail competition. Others (such as Georgia and Oregon) have opened retail electricity choice for large commercial and industrial customers but do not participate in restructured wholesale power markets (Zhou, 2017).

\subsection{Research on electricity market restructuring}

Electricity market restructuring studies have primarily focused on identifying theoretical benefits and examining empirical evidence. The theoretical benefits for market restructuring include more efficient power plant operations, lower electricity rates, greater customer choices, additional opportunities for new entrants, higher investment in new generation capacity, and greater adoption of innovative technology (Joskow, 2005; NERA Economic Consulting, 2008; Resources Editor, 1997). These potential benefits motivated the wave of U.S. market restructuring in the 1990s. Since then, academia and policy analysts have examined the effectiveness of market restructuring. This section reviews the literature related to power plant efficiency, electricity rates, and customer choices. This study will focus on rates and customer choice.

Regarding power plant performance, Markiewicz et al. (2004) found that the investor-owned power plants in restructured markets can reduce operating expenses by $3-5$ percent from efficiency gains by testing labor and nonfuel input costs. Chan et al. (2017) investigated the fuel efficiency and environmental impacts of coal-fired power plants in states with restructuring based on a panel data set from 1990 to 2005, 


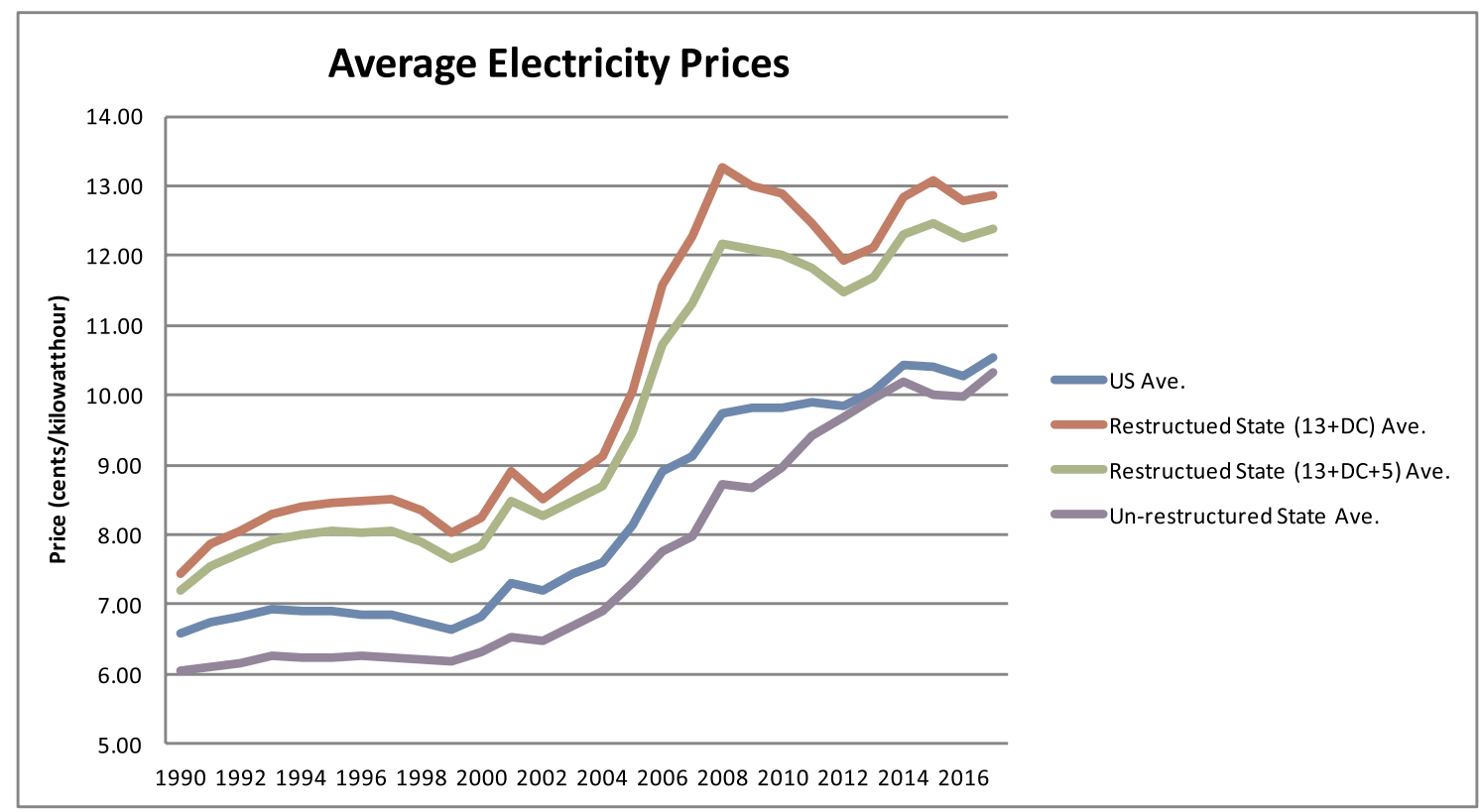

Fig. 5. Trends in nominal electricity rates.

Source: Data from the U.S. Energy Information Administration (2018).

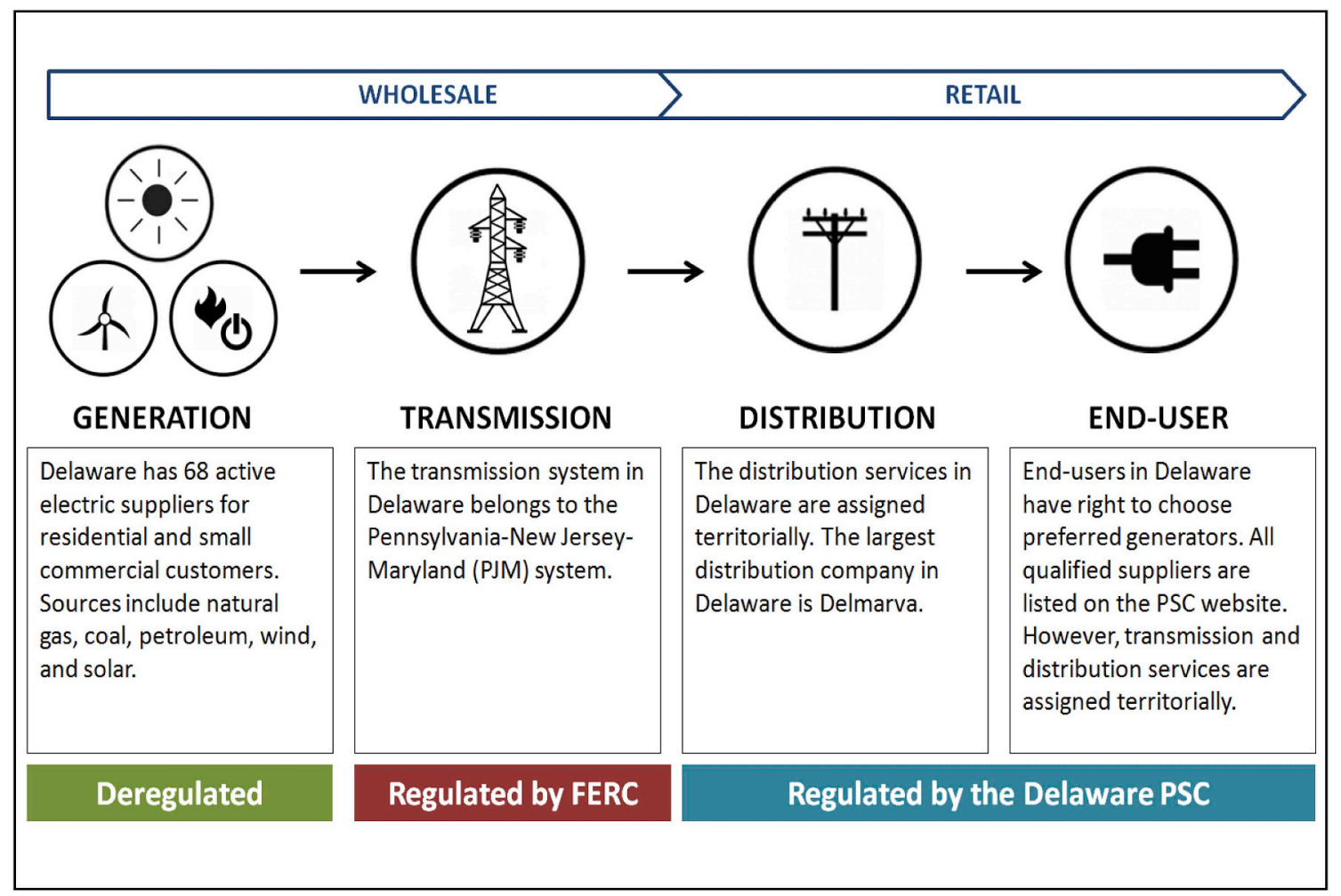

Fig. 6. Delaware electricity market structure and regulation.

Source: Data from the Delaware Public Service Commission (2018).

finding that restructuring led to a 1.4 percent improvement in fuel efficiency, nearly a 15 percent savings in operating expenses, and up to a 7.5 percent emissions reduction. Some studies reached the same conclusion for efficiency but noted that the restructuring has not met all potential benefits. For example, Borenstein and Bushnell (2000) argued that while electricity restructuring brought significant efficiency improvements in generation, the rates in restructured states were still higher than the rates in non-restructured states.
Electricity rates are believed to be a key indicator for evaluating the performance of market restructuring. Empirical studies of rates following restructuring have had mixed or contradictory findings. Carlson and Loomis (2008) assessed the deregulated market in Illinois and concluded that restructuring brought lower rates than those adjoining states (Indiana, Iowa, Kentucky, Missouri, and Wisconsin) with regulated rates. O'Connor (2017) evaluated the weighted average prices for residential, commercial, and industrial customers for 14 competitive 
Table 1

Top Five Electricity Utilities in Delaware in 2014 (Unit: megawatt hours).

\begin{tabular}{|c|c|c|c|c|c|c|c|}
\hline & Entity & Type of Provider & All Sectors & Residential (MWh) & Commercial (MWh) & Industrial (MWh) & Transportation (MWh) \\
\hline 1 & Delmarva Power and Light (DPL) & Investor-owned & $3,604,764$ & $2,673,209$ & 902,845 & 28,710 & 0 \\
\hline 2 & Delaware Electric Cooperative & Cooperative & $1,301,698$ & $1,060,347$ & 241,351 & 0 & 0 \\
\hline 3 & Direct Energy Business & Investor-owned & 709,072 & 0 & 709,072 & 0 & 0 \\
\hline 4 & City of Dover & Public & 703,096 & 199,449 & 227,978 & 275,669 & 0 \\
\hline \multirow[t]{3}{*}{5} & Noble Americas Energy Solutions LLC & Investor-owned & 587,391 & 0 & 543,682 & 43,709 & 0 \\
\hline & Total sales, top five providers & & $6,906,021$ & $3,933,005$ & $2,624,928$ & 348,088 & 0 \\
\hline & Percent of total state sales & & 61 & 85 & 63 & 14 & 0 \\
\hline
\end{tabular}

Source: Data from the the U.S. Energy Information Administration (2017)

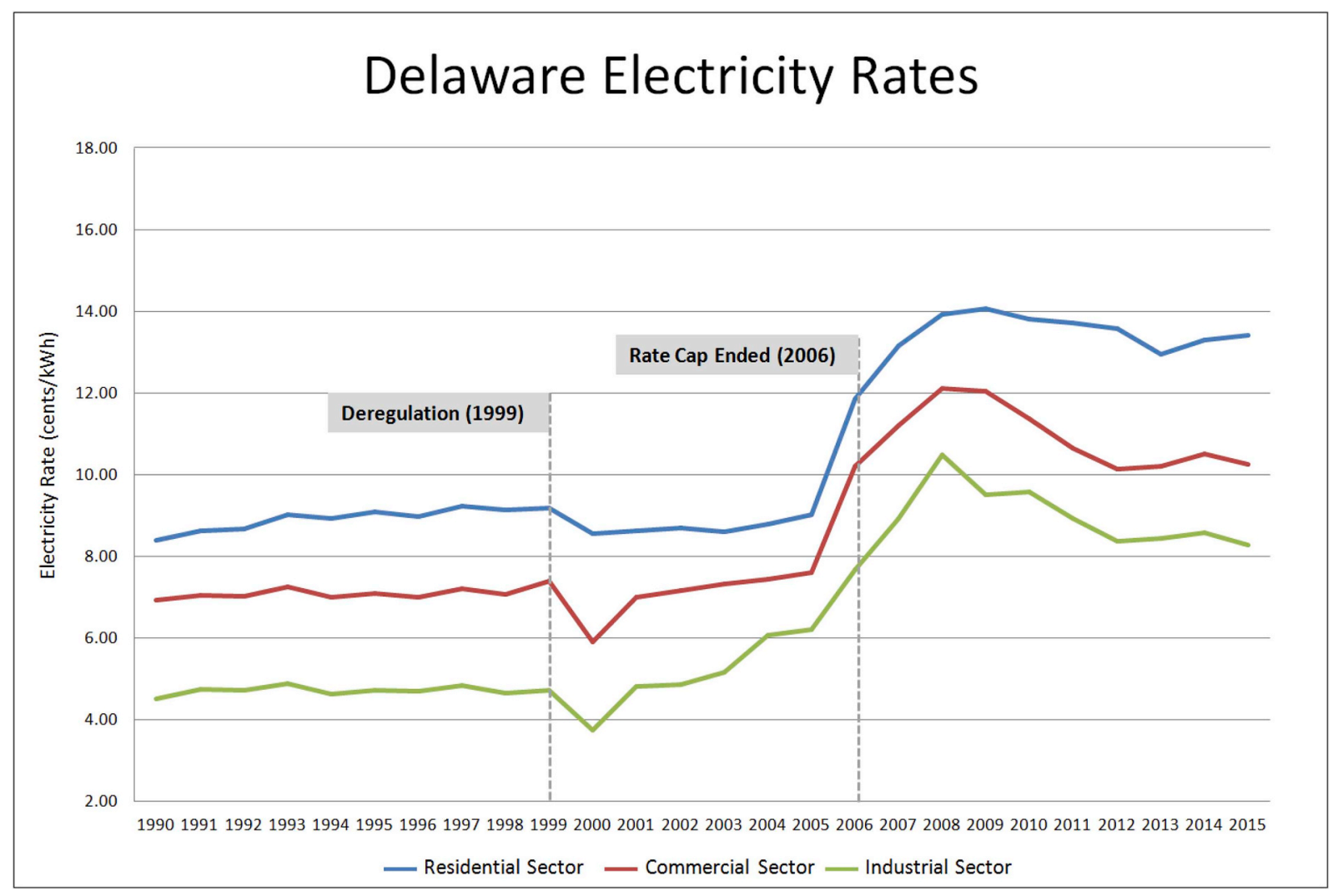

Fig. 7. Electricity rate trends in Delaware, 1990) to 2015.

Source: Data from the U.S. Energy Information Administration (2017).

Table 2

Average retail prices (cents/kWh).

\begin{tabular}{llll}
\hline Period & Residential & Commercial & Industrial \\
\hline Delaware pre-deregulation (1990-1999) & 8.92 & 7.09 & 4.70 \\
Delaware transition (2000-2005) & 8.71 & 7.07 & 5.14 \\
Delaware post-deregulation (2006-2015) & 13.38 & 10.86 & 8.87 \\
Delaware (2015) & 13.42 & 10.25 & 8.28 \\
US average (2015) & 12.65 & 10.64 & 6.91 \\
\hline
\end{tabular}

Source: Data from the U.S. Energy Information Administration (2018)

markets from 2008 to 2016 . The average prices of the commercial and industrial classes had a significant downward trend and the residential prices had flattened in competitive markets. The prices in non-restructured states showed an upward trend.

Blumsack et al. (2008) found that the price-cost margins were significantly higher in restructured markets because of productivity and efficiency improvement and that the gains from restructuring have benefited the producers rather than the consumers. Razeghi et al. (2017) noted that it is difficult to determine the impact of restructuring since the trends in electricity rates are similar in states with or without restructuring. Borenstein and Bushnell (2000) suggested that the electricity rate changes following restructuring were driven more by exogenous factors (i.e., natural gas price fluctuations and generation technology advances) than by the effects of restructuring.

Retail customer benefits, particularly consumer choice is another theoretical advantage of market restructuring. In theory, customers have the opportunity to choose alternative generators based on prices and services, as well as environmental or other factors. Retail markets allow customers to switch to new suppliers without changing distribution utilities. However, Hortaçsu et al. (2017) found that although customers had the "power to choose," they rarely search for alternate suppliers because of inertia. Morey et al. (2016) indicated that there is little evidence to show that retail choice has yielded significant benefits. Nor is the relationship between retail choice and residential customer satisfaction. Customer-focused analyses are growing as customer engagement opportunities are increasing in the electricity sector due to advanced technologies, such as smart meters and distributed renewable generation. 


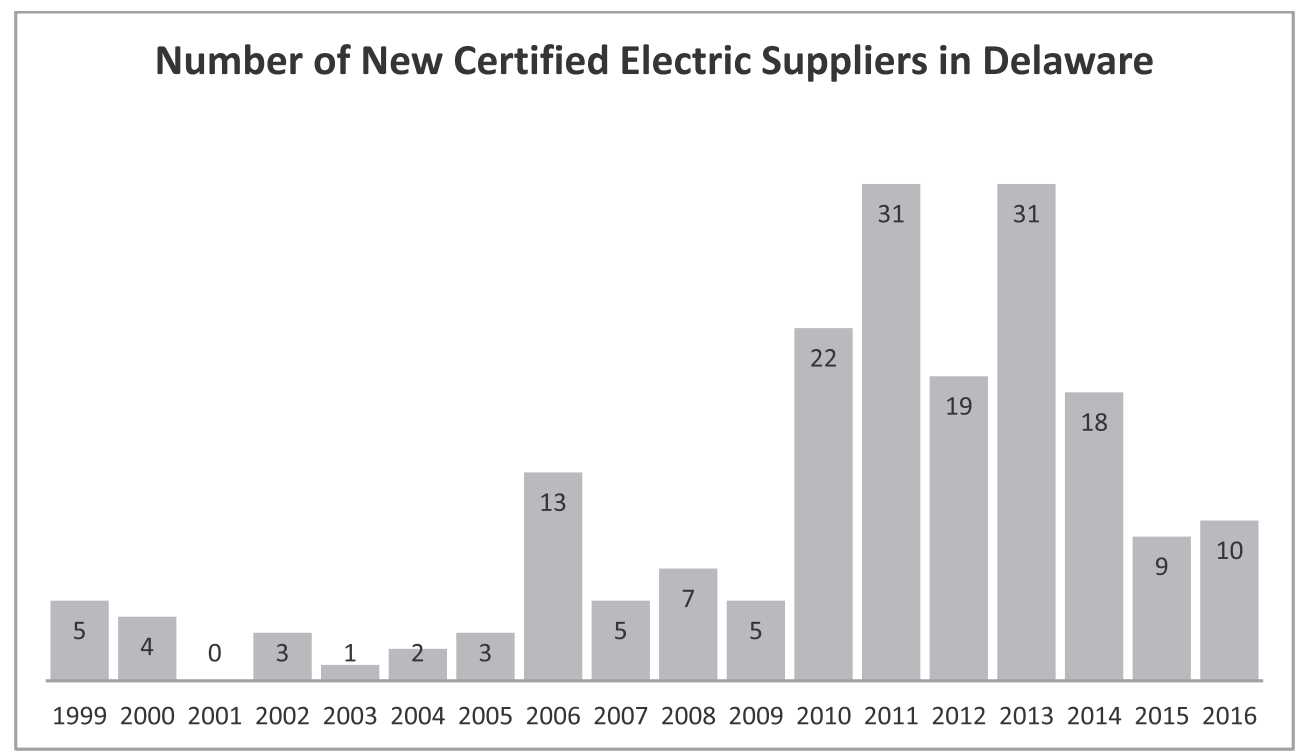

Fig. 8. New certified electric suppliers in Delaware.

Source: Data from the Delaware Public Service commission (2017a, 2017b).

Table 3

Rates for residential customers provided by various suppliers.

\begin{tabular}{|c|c|c|c|}
\hline Supplier & $\begin{array}{l}\text { Rate (cent/ } \\
\text { kWh) }\end{array}$ & Plan & Term \\
\hline DPL SOS & 6.96 & Standard offer service & None \\
\hline $\begin{array}{l}\text { Champion Energy } \\
\text { Services }\end{array}$ & 7.90 & Champ Saver 16 & 16 month \\
\hline Direct Energy & 7.89 & Live Brighter 12 & 12 month \\
\hline Direct Energy & 7.99 & Live Brighter 18 & 18 month \\
\hline Constellation & 7.45 & 6 Month Web Only & 6 month \\
\hline Constellation & 7.98 & 12 Month Web Only & 12 month \\
\hline Constellation & 8.39 & 24 Month Web Only & 24 month \\
\hline Constellation & 8.59 & $\begin{array}{l}12 \text { Month Web Only } \\
\text { (green) }\end{array}$ & 12 month \\
\hline Think Energy & 8.80 & The Unsurprise 6 Plan & 6 month \\
\hline Direct Energy & 9.09 & Connect to Comfort 24 & 24 month \\
\hline Think Energy & 9.20 & Rate Protection 24 Plan & 24 month \\
\hline
\end{tabular}

Source: Delmarva Power \& Light Co. (2017a) for summer billing months (June through September). Rates of alternative suppliers are retrieved from the Choose Energy website (www.chooseenergy.com) as of August 2017.

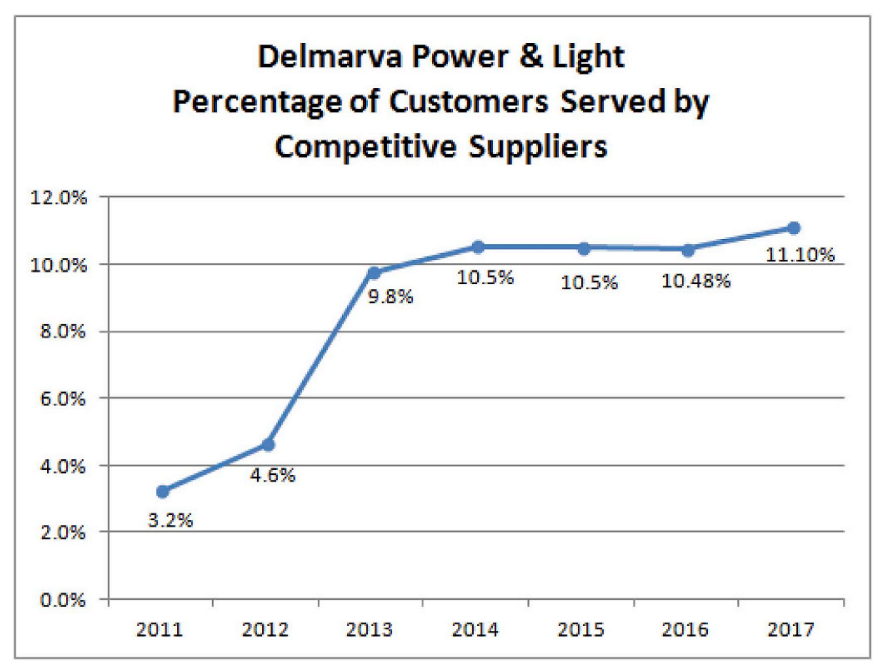

Fig. 9. Percentage of customers choosing alternative suppliers.

Source: Data from the Delaware Public Service Commission (2017b).

\section{Data and methodology}

This study adopts both quantitative and qualitative methodologies. The average retail rate for each state is collected from the U.S. Energy Information Administration (EIA) and is used to compare differences between states with or without market restructuring, using 1995 data to represent rates "before restructuring" and 2015 data to represent "after restructuring." Regarding Delaware, retail electric prices were analyzed for the years 1990-2016 with consideration that restructuring in the state was initiated in 1999. The electricity rate data is also derived from the U.S. EIA via Form 826. These data are detailed at the state level as well as the utility level.

Residential customers of Delmarva Power and Light (DPL) were chosen for the analysis, focusing on the period from 2009 to 2016 when the competitive market matured. Official documents, including rate cases submitted by DPL to the Delaware Public Service Commission (PSC), tariffs records, and government orders, were used for the qualitative analysis. These documents were retrieved from the DelaFile system $^{2}$ archived by the PSC. Some of the historical data for tariff and certified suppliers were collected through the Delaware Freedom of Information Act (FOIA) procedure.

\section{Comparing electricity prices between states with and without restructuring}

U.S. states deploy three types of retail service structures: restructured markets with customer choice (green in Fig. 2), restructured markets with some customer choice (green line in Fig. 2), and services provided by traditional regulated utilities (gray in Fig. 2). As mentioned, 13 states and the District of Columbia operate retail electricity markets where customers in all classes (residential, commercial and industrial) have opportunities to select the electricity generator they prefer. In the states of California, Oregon, Michigan, Georgia, and Virginia, some retail customers can shop for electricity (American Coalition of Competitive Energy Suppliers, 2018).

High electricity prices were one of the factors motivating market restructuring. Fig. 3 maps the electricity rate for each state in 1995

\footnotetext{
${ }^{2}$ DelaFile is the Delaware PSC's repository for all official filings, including applications, complaints, inquiries, and comments. For more detailed information, see: delafile.delaware.gov.
} 
Table 4

DPL rate cases.

\begin{tabular}{|c|c|c|c|c|c|c|}
\hline Rate Case & Filing Date & $\begin{array}{l}\text { Requested } \\
\text { Increase in Revenues }\end{array}$ & $\begin{array}{l}\text { Proposed } \\
\text { Increase as a Percentage of Total Revenues }\end{array}$ & Proposed ROE & $\begin{array}{l}\text { Authorized Revenue } \\
\text { Increase (Decrease) }\end{array}$ & Authorized ROE \\
\hline \# 09-414 & Sep. 18, 2009 & $\$ 27,618,487$ & $4.0 \%$ & $10.8 \%$ & $\$ 16,371,203$ & $10.0 \%$ \\
\hline \# 11-528 & Dec. 02, 2011 & $\$ 31,760,741$ & $19.2 \%$ & Not specified & $\$ 22,000,000$ & $9.8 \%$ \\
\hline \# 13-115 & Mar. 22, 2013 & $\$ 42,044,000$ & $7.4 \%$ & $10.3 \%$ & $\$ 15,096,574$ & $9.7 \%$ \\
\hline \# 16-0649 & May 17, 2016 & $\$ 62,766,280$ & $10.6 \%$ & $10.6 \%$ & $\$ 31,500,000$ & $9.7 \%$ \\
\hline \# 17-0977 & Aug. 17, 2017 & $\$ 24,425,436$ & $4.5 \%$ & $10.1 \%$ & $-\$ 6,850,000$ & $9.7 \%$ \\
\hline
\end{tabular}

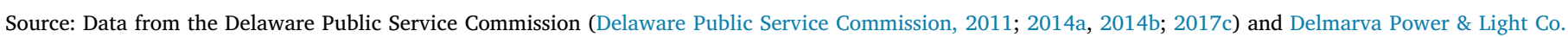
(Delmarva Power and Light Co., 2009, 2011, 2013, 2016, 2017b).

(before restructuring) and 2015 (about 20 years after restructuring). The electricity rates of the restructured states are still relatively high, similar to the situation 20 years ago. As of 2015, the US average is 10.40 cents/kWh, the non-restructured states average is 9.21 cents/ $\mathrm{kWh}$, and the restructured states average is 12.83 cents $/ \mathrm{kWh}$.

Fig. 4 plots the electric rates for all states and DC in 1995 and 2015. States with restructured markets (blue triangles) were distributed in the higher rate zones in both years.

Fig. 5 presents annual nominal electricity rates from 1990 to 2016. A rising trend of nominal electric prices is revealed in all states, with and without restructuring. The average electricity prices of restructured states were higher than non-restructured states. Of course, the association displayed in the figure cannot be interpreted as a causal effect.

\section{Case study of Delaware}

\subsection{Electric industry structure in Delaware}

Delaware began restructuring its electricity sector in 1999. With the market restructuring, power generation was deregulated and customers were empowered to choose among the competing generation suppliers. Fig. 6 illustrates the market structure and regulation. Delaware currently has 68 active electric suppliers for residential and small commercial customers. Power transmission and the wholesale market is operated by the $\mathrm{PJM}^{3}$ Interconnection LLC (PJM) and governed by the FERC. The Delaware PSC oversees investor-owned distribution services (Delaware Public Service Commission, 2018).

The top five electricity distribution utilities in Delaware are listed in Table 1, with end-use consumption information in megawatt hours. DPL is the largest investor-owned utility, serving residential, commercial, and industrial customers. The following analysis focuses on DPL's operation.

\subsection{Retail rate trends}

The deregulation legislation in Delaware provided a retail electricity rate cap for seven years starting in 1999. At the beginning of the restructuring, residential rates were decreased based on an agreement between the utilities and the state and rates for residential and small commercial customers were frozen through 2005 . When the cap came off in 2006, residential customers encountered a 59 percent increase, rates for small commercial customers rose by 67 percent, and rates for large commercial and industrial customers rose by 118 percent (Kaye Scholer LLP et al., 2007). After the dramatic rate change in 2006, the rates continued to shift for various reasons, including fuel prices, state renewable energy policies, smart meter installation, and distribution reliability enhancement. These reasons will be analyzed in detail later,

\footnotetext{
${ }^{3}$ PJM Interconnection, formally Pennsylvania New Jersey Maryland Interconnection LLC. PJM coordinates the wholesale electricity in all or parts of Delaware, Illinois, Indiana, Kentucky, Maryland, Michigan, New Jersey, North Carolina, Ohio, Pennsylvania, Tennessee, Virginia, West Virginia and the District of Columbia.
}

but the rate trend is graphed in Fig. 7.

The comparison between the average rates in the pre-deregulation, transition, and post-deregulation periods can be found in Table 2 . Overall, Delaware customers had smaller bills during the pre-deregulation and transition periods than in the post-deregulation period. Additionally, customers in Delaware paid more than the national average. Compared to other states and the US average, the 2015 average rates for the residential class was 13.42 cents $/ \mathrm{kWh}$ in Delaware, six percent greater than the national average rate of 12.65 cents/ kWh. For industrial customers, Delaware's rate was 8.28 cents/kWh, significantly higher than the national average of 6.91 cents $/ \mathrm{kWh}$. Only the commercial customers enjoyed comparable rates of 10.25 cents/ $\mathrm{kWh}$ in Delaware and 10.64 cents/kWh for national average (U.S. Energy Information Administration, 2018). Again, no causal relationship is implied.

\subsection{Retail choice}

Customer choice of electric supplier is considered a major benefit. The Delaware PSC has been issuing electric supplier certificates since 1999. Fig. 8 shows the number of new suppliers that received certification in Delaware each year since 1999. As of August 2017, residential customers within the DPL service territory had 68 certified suppliers to choose from, including brokers (Delaware Public Service Commission, 2017a; 2017b). The Delaware PSC maintains a list of electricity suppliers certified to do business in Delaware and updates their contact information on the PSC website. Additionally, DPL distributes a brochure entitled "Electricity Supply Choice" to its customers with certified supplier's information, as well as information on what, why, and how to choose alternative suppliers. Consumers who intend to switch power suppliers can access additional information. Regarding rate comparison, many energy service companies provide tools to assist customers in estimating and comparing bill amounts by various suppliers. For example, on the website of Choose Energy, consumers can input their electricity usage and utility company (using their address zip code) to find all service plans and rates. These information tools facilitate customer switching. However, customers still need to actively compare rates and services, choose a supplier, enroll in a program, sign a contract, and inform their utility of the transfer.

More choice, however, does not necessarily mean less expensive choice. In Delaware, suppliers offer various plans with different rates. Table 3 shows featured options for a residential customer in the DPL service territory. Customers who do not shop for competitive rates pay a default rate known as the "standard offer service" (SOS). Among all the options, DPL's SOS rate for residential customers in August 2017 was 6.96 cents/ $\mathrm{kWh}$, which is the lowest rate in comparison to the other suppliers. Customers with a green energy preference could choose Constellation for a fixed rate of 8.59 cents/kWh for 12 months with a $\$ 150$ early termination fee.

In the 2013 to 2017 period, only about ten percent of DPL's residential customers switched to alternative suppliers (Fig. 9), even though retail choice was available. A key reason might be the noncompetitive rates. Another explanation is that customers who selected 
alternative suppliers usually enjoyed a fixed-rate contract, but experienced a sudden spike in rates after the end of the contract without prior notice. The Delaware PSC received 53 complaints from customers across four different suppliers during the first two months of 2014 for dramatic price increases. Residential customers with third-party contracts received bills "as high as $\$ 950$, triple than what the rate had been under contract the month before" (Nathans, 2014a). In a restructured market, customers must pay attention to the month-to-month variable rates if they choose third-party suppliers. By contrast, DPL sets PSC approved SOS rates on a rolling three-year basis, so the rates tend to change slowly (Nathans, 2014b).

In short, market restructuring, in theory, provides retail choices and competitive rates. Customers are able to switch to new suppliers without power disconnection. However, competitive rates may not be less expensive. Customers need to understand their electricity consumption pattern and have sufficient information to make a sound choice and bear the risk of price volatility after contract expiration.

\section{Electric rate case analysis}

DPL is the largest investor-owned utility in Delaware, providing electricity to about 57 percent of total retail customers (residential, commercial, and industrial) and about 60 percent $(250,000)$ of residential customers in Delaware as of 2017 (U.S. Energy Information Administration, 2017). The primary services that DPL provides are distribution of electricity, purchasing electricity in the wholesale market for its SOS customers, and preparing bills. Because DPL is an investor-owned company, its rates must be reviewed by the PSC. The PSC establishes the amount of revenue that the DPL can collect from customers to cover the costs and earn a fair rate of return (Alt, 2006).

Since 2009, DPL has submitted five rate increase requests for PSC's approval with the justifications of enhancing system reliability and safety, diversifying the energy supply portfolio, expanding and improving the customer service, and modernizing its infrastructure. The PSC usually takes one to two years to evaluate and make their final decision on each request. Table 4 lists the rate raise requests filing date, the requested increase amount and percentage, proposed and approved rate of equity (ROE) and final approval increase amounts. All cases were settled with authorized revenue increase and ROE.

The requested increase in revenues in Table 4 refers to the increase annual revenues from "base rates" proposed by DPL. The requested amounts grew from \$27.6 million in 2009 to $\$ 62.7$ million in 2016 . Improvements to reliability were one of the main reasons why DPL sought to increase rates. The PSC approved all requests with lower amounts, the ratio ranging from 35.7 percent to 69.3 percent of that requested. In other words, DPL was allowed to raise revenues by $\$ 85.2$ million during 2009-2016. DPL submitted a new request in August 2017, five months after the PSC approved an increase; the request was modified twice after the initial submission. In this case, DPL agreed to a net decrease of $\$ 6.85$ million to base revenues, to reflect the impact of the Tax Cuts and Jobs Act, which reduced the corporate income tax rate from $35 \%$ to $21 \%$ effective in 2018 .

In addition to the regular rate increase requests, DPL proposed in 2017 to add a new Distribution System Improvement Charge. The company's regional president claimed that the new monthly charge will reduce the frequency of rate cases, asserting that "it is more efficient, saving our customers millions of dollars in the years ahead" (Stockbridge, 2017).

A typical customer could find rate information from local newspaper reporting and the PSC website. However, the conversion of DPL's changes to revenues to customer bills is not always clear.

\section{Conclusions and policy implications}

After twenty years of evolution in market restructuring, the U.S. electricity industry is not simply a dichotomy between competitive markets and regulated monopolies. Regional and state structures have become more diverse and regulation is implemented at various levels and scopes, making it challenging to make general conclusions. However, with twenty years of experience, the state of Delaware provides some policy implications.

First, the primary theoretical benefits of a competitive market are lower prices and more choices. After the removal of price caps in Delaware, however, DPL customers received a larger bill. Retail competition has not driven prices downward. The regulated utility with larger market share, based on SOS, still has advantages to provide lower and more stable rates. In practice, only around 10 percent of the DPL residential customers have switched their electric suppliers. Second, further studies focusing on mechanisms to protect retail customers are necessary. Although customers are empowered to choose their electricity suppliers, little evidence shows that consumers benefited, especially in terms of rates. In fact, the customer seems to be the "missing piece" in the restructuring movement (Haar, 2004). Retail customers have little influence over their electric rates and it has become more difficult for them to control their bill solely through reducing consumption. Although the fundamental responsibility of the state utility commission is to protect the public interest (including customer interest) (Haar, 2004), the welfare and satisfaction of customers deserve more attention from policymakers and electric market designers.

To conclude, market restructuring in Delaware has not achieved the theoretical benefits in terms of prices and choices. However, in today's dynamic and fast-changing electricity sector, restructuring may provide other benefits than those expected twenty years ago, including a flexible market structure for integrating new technologies. Additional research is needed to understand the complexity of the electricity industry and its regulation today as well as policies and mechanisms to protect consumers.

\section{Acknowledgments}

This research was supported by the Center for Applied Demography and Survey Research at the University of Delaware. The author sincerely thanks Prof. Edward C. Ratledge, Dr. Pamela S. Willrodt, Dr. Janice Beecher, Rebecca Gross and two anonymous reviewers for insightful comments and suggestions.

\section{References}

Alt, L., 2006. Energy Utility Rate Setting. Lulu.Com.

American Coalition of Competitive Energy Suppliers, 2018. State-by-state information [WWW Document]. http://competitiveenergy.org/consumer-tools/state-by-statelinks/ Accessed 8.7.2018.

Blumsack, S., Lave, L., Apt, J., 2008. Electricity Prices and Costs under Regulation and Restructuring. Social Science Research Network, Rochester, New York.

Borenstein, S., Bushnell, J., 2000. Electricity Restructuring: Deregulation or Reregulation? (SSRN Scholarly Paper No. ID 235865). Social Science Research Network, Rochester, New York.

Brockway, N., 2007. Delaware's Electricity Future: Re-regulation Options and Impacts. Boston.

Carlson, J.L., Loomis, D., 2008. An assessment of the impact of deregulation on the relative price of electricity in Illinois. Electr. J. 21, 60-70. https://doi.org/10.1016/j. tej.2008.07.004.

Chan, H.R., Fell, H., Lange, I., Li, S., 2017. Efficiency and environmental impacts of electricity restructuring on coal-fired power plants. J. Environ. Econ. Manag. 81, 1-18. https://doi.org/10.1016/j.jeem.2016.08.004.

Cicchetti, C.J., Dubin, J.A., Long, C.M., 2004. The California Electricity Crisis: what, Why, and What's Next. Kluwer Academic Publishers, Norwell.

Delaware Public Service Commission, 2011. Order No. 7897.

Delaware Public Service Commission, 2014a. Order No. 8561.

Delaware Public Service Commission, 2014b. Order No. 8589.

Delaware Public Service Commission, 2017a. Current List of Certified Electric Suppliers. Updated 7-31-2017.

Delaware Public Service Commission, 2017b. Delaware public service commission (PSC) state of Delaware. Customer Electric Choice [WWW Document]. http://depsc. delaware.gov/customer-electric-choice/ Accessed 8.17.17.

Delaware Public Service Commission, 2017c. Order No. 9166.

Delaware Public Service Commission, 2018. Electric Regulation [WWW Document]. Delaware Public Service Commission (PSC), State of Delaware. http://depsc. delaware.gov/electric-regulation/ Accessed 6.19.17. 
Delmarva Power \& Light Co, 2009. Delmarva Power \& Light Company's Application for an Increase in Electric Base Rates Docket No. 09-414.

Delmarva Power \& Light Co, 2011. Delmarva Power \& Light Company's Application for an Increase in Electric Base Rates Docket No. 11-528.

Delmarva Power \& Light Co, 2013. Delmarva Power \& Light Company's Application for an Increase in Electric Base Rates Docket No. 13-115.

Delmarva Power \& Light Co, 2016. Delmarva Power \& Light Company's Application for an Increase in Electric Base Rates and Miscellaneous Tariff Changes, Docket No. 16 0649.

Delmarva Power \& Light Co, 2017a. Delaware Electric Tariff.

Delmarva Power \& Light Co, 2017b. Delmarva Power \& Light Company's Application for an Increase in Electric Base Rates Docket No. 17-0977.

Electric Choice, 2017. Map of Deregulated Energy States (updated 2017) [WWW Document]. Electric Choice. https://www.electricchoice.com/map-deregulatedenergy-markets/ Accessed 9.10.18.

Haar, B.W., 2004. Impact of deregulation on the task of commission control. Utilities Policy, The Limitations of Deregulation Revisited 12, 193-202. https://doi.org/10. 1016/j.jup.2004.04.004

Hogan, W.W., 2002. Electricity market restructuring: reforms of reforms. J. Regul. Econ. 21, 103-132. https://doi.org/10.1023/A:1013682825693.

Hortaçsu, A., Madanizadeh, S.A., Puller, S.L., 2017. Power to choose? An analysis of consumer inertia in the residential electricity market. Am. Econ. J. Econ. Policy 9 192-226. https://doi.org/10.1257/pol.20150235.

International Energy Agency, 2001. Competition in Electricity Markets. Organisation for Economic Co-operation and Development, Paris.

Joskow, P.L., 2000. Deregulating and Regulatory Reform in the U.S. Electric Power Sector. Presented at the the Brookings-AEI Conference on Deregulation in Network Industries. MIT Center for Energy and Environmental Policy Research, Cambridge, Massachusetts.

Joskow, P.L. 2005. The difficult transition to competitive electricity markets in the United States. In: Electricity Deregulation: Choices and Challenges. The University of Chicago Press, Chicago.

Kaye Scholer LLP, 2007. State Analysis and Survey on Restructuring and Re-regulation. Levitan \& Associates, Inc., Semcas Consulting Associates.

Markiewicz, K., Rose, N.L., Wolfram, C., 2004. Do Markets Reduce Costs? Assessing the Impact of Regulatory Restructuring on U.S. Electric Generation Efficiency. National
Bureau of Economic Research (Working Paper No. 11001). https://doi.org/10.3386/ w11001.

Morey, M., Kirsch, L., Christensen Associates Energy Consulting, L.L.C., 2016. Retail Choice in Electricity: what Have We Learned in 20 Years. Madison, USA.

Munson, R., 2005. From Edison to Enron: the Business of Power and what it Means for the Future of Electricity. Praeger, Westport, Conn.

Nathans, A., 2014a. Delmarva Customers Urged to Check Third-Party Contracts. The News Journal, Wilmington, Del.

Nathans, A., 2014b. Electric Customers Feel Winter's Costly Impact. The News Journal, Wilmington, Del.

NERA Economic Consulting, 2008. Competitive Electricity Markets: the Benefits for Customers and the Environment. NERA Economic Consulting, Boston, Massachusetts.

O'Connor, P., 2017. Restructuring Recharged: the Superior Performance of Competitive Electricity Markets 2008-2016. Retail Energy Supply Association, Hummelstown, Pennsylvania.

Purdue University Energy Center, n.d. Electric utilities, deregulation and restructuring of U.S. electricity markets [WWW Document]. URL https://www.purdue.edu/ discoverypark/energy/assets/pdfs/History.pdf (Accessed 9.18.17).

Razeghi, G., Shaffer, B., Samuelsen, S., 2017. Impact of electricity deregulation in the state of California. Energy Policy 103, 105-115. https://doi.org/10.1016/j.enpol. 2017.01.012.

Resources Editor, 1997. Electricity deregulation and the consumer. Resources for the Future(126).

Sioshansi, F.P., 2006. Electricity market reform: what has the experience taught us thus far? Util. Pol. 14, 63-75. https://doi.org/10.1016/j.jup.2005.12.002.

Stockbridge, G., 2017. Electric rate plan will save millions for customers. The News Journal; Wilmington, Del. A. 7.

U.S. Energy Information Administration, 2017. Form EIA-861M (formerly EIA-826) [WWW Document]. https://www.eia.gov/electricity/data/eia861m/index.html Accessed 8.16.17.

U.S. Energy Information Administration, 2018. 1990-2015 Average price by state by provider (EIA-861 Form) [WWW Document]. https://www.eia.gov/electricity/data/ state/ Accessed 7.7.17.

Zhou, S., 2017. An Introduction to Retail Electricity Choice in the United States (No. NREL/BR-6A50-68993). National Renewable Energy Lab. (NREL), Golden, CO (United States), Golden, Colorado. 